\title{
Log10 per Milliliter
}

National Cancer Institute

\section{Source}

National Cancer Institute. Log 10 per Milliliter. NCI Thesaurus. Code C73570.

A log arithmic-scale (base 10) potency unit measured per milliliter. 